\title{
Essential oil composition and cytotoxic activity in two species of the plant genus Vismia (Hypericaceae) from the Venezuelan Andes
}

\author{
Janne Rojas-Vera $^{1 *}$, Alexis Buitrago Díaz ${ }^{1,2}$, Francisco A. Arvelo ${ }^{3,4}$, Felipe J. Sojo ${ }^{3,4}$,
} Alírica I. Suarez ${ }^{5} \&$ Luis Rojas $^{6}$

1. Biomoléculas Orgánicas Research group, Research Institute, Faculty of Pharmacy and Bioanalysis, University of Los Andes, Mérida, Venezuela; janner@ula.ve

2. Analysis and Control Department, Faculty of Pharmacy and Bioanalysis, University of Los Andes, Mérida, Venezuela; alexisb@ula.ve

3. Bioscience Center, Foundation of Advanced Studies Institute, Sartenejas Valley, Miranda State, Venezuela; franarvelo@yahoo.com

4. Tissue Cultivation and Tumor Biology Laboratory, Experimental Biology Institute, Central University of Venezuela, Los Ilustres Avenue, Caracas, Venezuela; felipesojo@gmail.com

5. Natural Products, Faculty of Pharmacy, Central University of Venezuela, Los Ilustres Avenue, Caracas, Venezuela; alirica1@yahoo.es

6. Research Institute, Faculty of Pharmacy and Bioanalysis, University of Los Andes, Mérida, Venezuela; rojasl@ula.ve * Correspondence

Received 31-X-2019. Corrected 08-III-2020. Accepted 03-VI-2020.

\begin{abstract}
Introduction: The Vismia genus belongs to the Hypericaceae family and comprises around 57 species of which 17 have been located in Venezuela. Previous investigations have been carried out in extracts as well as pure isolated compounds, revealing antimicrobial, antioxidant and anti-HIV, among other, biological activities. Objective: This investigation aims to determine the cytotoxic activity of essential oils from leaves of Vismia baccifera Triana \& Planch (VBJ and VBV) and Vismia macrophylla Kunth (VM) collected in three different locations of the Venezuelan Andean region. Methods: Essential oils obtained by hydrodistillation were analyzed using gas chromatography-mass spectrometry (GC-MS) and their cytotoxic activity was analyzed following the MTT (3-[4,5-dimethylthiazol-2-yl]-2,5-diphenyltetrazolium bromide) assay. Human tumor cell lines from SKBr3, MCF-7 and PANC-1, two breast carcinomas and one pancreatic adenocarcinoma of ductal type, were tested with the oil samples and human dermis fibroblasts were used as non-tumor cells. Results: $\beta$-caryophyllene and trans-caryophyllene were present as major components in VBJ and VBV, respectively, while $\gamma$-bisabolene was the main component in the VM sample. Anticancer activity was observed on $V$. baccifera essential oil against SKBr3, MCF-7 and PANC-1. The selectivity index showed that VBV is highly selective against the SKBr3 cell line and has no activity against non-tumor cells. Conclusions: These results are considered a contribution to natural products research and may provide supportive data for future studies on cancer.
\end{abstract}

Key words: fibroblasts; $\beta$-caryophyllene; $\gamma$-bisabolene; MTT; MCF-7; PANC-1; SKBr3.

Rojas-Vera, J., Buitrago Díaz, A., Arvelo, F.A., Sojo, F.J., Suarez, A.I., \& Rojas, L. (2020). Essential oil composition and cytotoxic activity in two species of the plant genus Vismia (Hypericaceae) from the Venezuelan Andes. Revista de Biología Tropical, 68(3), 884-891.

The Vismia genus belongs to Hypericaceae family and comprises around 57 species distributed mainly in Neotropical zones, from South of Mexico, passing through Central America till they reach North of Brazil, in South America; only a few species have been reported for the tropical areas of Africa (Angiosperm Phylogeny Group, 2009; Crocketta \& Robson, 2011; Ruhfel et al., 2011; Hussain et al., 2012). In Venezuela, there are approximately 17 species, 
being Vismia baccifera Triana \& Planch and Vismia macrophylla Kunth the most common and well distributed species around the country (Aristiguieta, 1973; Stevens, 2007).

Previous investigations have reported 161 compounds isolated from different Vismia species where anthrones, xanthones, lignans, benzophenones and anthraquinones are the most frequent types of components observed (Hussain et al., 2012; Vizcaya, Morales, Rojas, \& Nuñez, 2012). Regarding biological properties, several investigations have been carried out either in extracts or pure isolated compounds, reveling antimicrobial (Buitrago et al., 2015; Vizcaya et al., 2014; Silvestre et al., 2012), antioxidant (Tala et al., 2011; Silvestre et al., 2012; Buitrago, Rojas, Rojas, \& Peñaloza, 2016), anti-VIH (Gómez-Cansino et al., 2015), anti-inflammatory, antinociceptive (Ferreira et al., 2015), parasiticidal, cardiotonic (Gomes et al., 2009) and cytotoxic (Salas, Rojas, Morales, Ramos-Nino, \& Colmenares, 2008; Rojas, Buitrago, Arvelo, Sojo, \& Suarez, 2017), among other, biological activities.

Essential oils have also been studied on Vismia species; from these, several monoterpenes and sesquiterpenes have been reported, being germacrene $\mathrm{D}, \alpha / \beta$-selinene, $\alpha$-cadinol, $\delta$-cadinene, valencene, $\beta$-elemene, $\alpha$-humulene and $\beta$-caryophyllene the most commonly detected (Buitrago et al., 2009; Rojas et al., 2011; Silvestre et al., 2012; Buitrago et al., 2015). The present investigation aims to determine the cytotoxic activity of essential oils from leaves of $V$. baccifera and $V$. macrophylla collected in the Venezuelan Andes.

\section{MATERIALS AND METHODS}

Plant material: Vismia macrophylla (VM) was collected from Michelena, Táchira state, at 1200 m.a.s.1. (7०56'30" N \& 72'14'33" $\mathrm{W}$ ), whereas $V$. baccifera (VB) was harvested from two different locations in Mérida state: Jaji (VBJ) at 1709 m.a.s.l. (8³4'54" $\left.\mathrm{N} \& 71^{\circ} 18^{\prime} 07^{\prime \prime} \mathrm{W}\right)$ and El Valle (VBV) at 1 835 m.a.s.1. ( $\left.8^{\circ} 38^{\prime} 13^{\prime \prime} \mathrm{N} \& 71^{\circ} 07^{\prime} 37^{\prime \prime} \mathrm{W}\right)$. Both species were collected in February 2017, during the rainy season and flowering stage. Botanical identification was carried out by Dr. Pablo Meléndez, MERF Herbarium, Faculty of Pharmacy and Bioanalysis, University of Los Andes, Mérida, Venezuela. Voucher specimens were deposited under the following codes: VM-JR39, VBJ-JR47 and VBV-JR51.

Isolation of essential oils: Leaves (1320 g, Jaji sample; 2000 g, El Valle sample; 1600 g, Michelena sample) were cut into small pieces and subjected, separately, to hydrodistillation for $4 \mathrm{~h}$, using a Clevenger-type apparatus. The oils ( $2 \mathrm{ml}, 0.15 \% \mathrm{w} / \mathrm{v}$ yield, Jaji sample; $2.5 \mathrm{ml}, 0.13 \% \mathrm{w} / \mathrm{v}$ yield, El Valle sample; $2.1 \mathrm{ml}, 0.13 \% \mathrm{w} / \mathrm{v}$ yield, Michelena sample) were dried over anhydrous sodium sulfate and stored at $4{ }^{\circ} \mathrm{C}$.

Gas chromatography (GC): GC analyses were performed on a Perkin-Elmer AutoSystem gas chromatograph equipped with flame ionization detectors. Two capillary columns of different polarities were used: a $5 \%$ phenylmethyl polysiloxane fused-silica column (AT-5, Alltech Associates Inc., Deerfield, IL) $(60 \mathrm{~m} \times$ $0.25 \mathrm{~mm}$, film thickness $0.25 \mu \mathrm{m}$ ) and a polyethylene glycol fused-silica column (AT-WAX, Alltech Associates Inc., Deerfield, IL) of the same dimensions. The initial oven temperature was $60{ }^{\circ} \mathrm{C}$; it was then heated to $260{ }^{\circ} \mathrm{C}$ at $4{ }^{\circ} \mathrm{C} /$ min and the final temperature was maintained for $20 \mathrm{~min}$. The injector and detector temperatures were $200^{\circ} \mathrm{C}$ and $250^{\circ} \mathrm{C}$, respectively. The carrier gas was helium at $1.0 \mathrm{ml} / \mathrm{min}$ and the sample was injected using a split ratio of 1:100. Retention indices were calculated relative to $\mathrm{C}_{8}-\mathrm{C}_{24}$ n-alkanes, using only the AT-5 capillary column and comparing values reported in the literature (Davies, 1990; Adams, 2007).

\section{Gas chromatography-mass spectrom-} etry (GC-MS): GC-MS analyses were carried out on a Hewlett Packard GC-MS system, Model 5973, fitted with a $30 \mathrm{~m}$ long, crosslinked $5 \%$ phenylmethyl siloxane (HP5MS, Hewlett Packard, USA) fused-silica column $(0.25 \mathrm{~mm}$, film thickness $0.25 \mu \mathrm{m})$. 
The following conditions were applied: source temperature $230{ }^{\circ} \mathrm{C}$; quadrupole temperature $150{ }^{\circ} \mathrm{C}$; carrier gas helium, adjusted to a linear velocity of $34 \mathrm{~m} / \mathrm{s}$; ionization energy, 70 eV; scan range 40-500 amu; 3.9 scans/s. The injected volume was $1.0 \mu \mathrm{l}$ of a $2 \%$ dilution of oil in n-heptane. A Hewlett-Packard ALS injector was used with a split ratio of 1:100. The identification of the oil components was based on the Wiley Registry of Mass Spectral Data ( $6^{\text {th }}$ ed.) and NIST 05 data base library, followed by comparisons of mass spectral (MS) data with published literature (Adams, 2007) and the retention index calculation.

\section{Human tumor cell lines and culture} media: Human tumor cell lines from MCF-7 (breast carcinoma, without over-expression of the HER2/cerb-2) and PANC-1 (pancreatic adenocarcinoma ductal type) were provided by Dr Marie France Poupon, Curie Institute, Paris, France. SKBr3 (breast carcinoma, in which the HER2/cerb-2 gene is overexpressed) was provided by Dr Manuel Rieber, IVIC Caracas, Venezuela. Primary culture human dermis fibroblasts (Hdf), used as non-tumor cells, were obtained from the Laboratory of Tissue Culture and Tumor Biology, Institute of Experimental Biology (Caracas, Venezuela). MCF-7, PANC1, SKBr3, and Hdf were grown in Dulbecco's Modified Eagle Medium (DMEM; Gibco) supplemented with $10 \%(\mathrm{v} / \mathrm{v})$ heat inactivated fetal bovine serum (FBS; Gibco), $1 \%$ of L-glutamine, $1 \%$ streptomicyn $\AA / 100$ units $/ \mathrm{ml}$ penicillin ${ }^{\circledR}($ Gibco). All cells were incubated at $37{ }^{\circ} \mathrm{C}$ with an atmosphere composed by $5 \%$ of $\mathrm{CO}_{2}$ and $95 \%$ humidity.

Cytotoxic activity assay: This analysis was carried out following the MTT (3-[4,5-dimethylthiazol-2-yl]-2,5-diphenyltetrazolium bromide) assay. This method is based on the conversion of MTT (yellow tetrazolium salt) to purple formazan crystals by living cells that determines mitochondrial reductases activity (Mosmann, 1983; van Meerloo, Kaspers, \& Cloos, 2011). Cell lines were used to determine the cytotoxic activity of the essential oils of the VM, VBJ and VBV samples. Samples at concentrations of $0.001,0.01,0.1,1,5,10$, 15,25 and $100 \mu \mathrm{g} / \mathrm{ml}$ were placed along with a positive control $\left(\mathrm{Taxol}^{\circledR}\right)$ in 96-well plates $\left(5 \times 10^{3}\right.$ cells/well $)$ and incubated at $37{ }^{\circ} \mathrm{C}$ with $5 \% \mathrm{CO}_{2}$ for $24 \mathrm{~h}$, to allow cells adhesion. After incubation time, $50 \mu \mathrm{l}$ of sample dilutions and reference drug were added and re-incubated at $37{ }^{\circ} \mathrm{C}$ with $5 \% \mathrm{CO}_{2}$ for 3 days. After $72 \mathrm{~h}$ of incubation, the culture medium was removed and cells were treated with 50 $\mu \mathrm{l}$ of MTT at a concentration of $0.4 \mathrm{mg} / \mathrm{ml}$, allowing the formation of formazan crystals during 3 hours. These solid crystals were dissolved in $50 \mu \mathrm{l}$ of DMSO and optical density was measured at $570 \mathrm{~nm}\left(\mathrm{DO}_{570}\right)$ by using an ELISA spectrophotometer (Sunrise ${ }^{\mathrm{TM}}$ TECAN, Switzerland) (Raybaudi-Massilia et al., 2015; Suárez et al., 2016). Assays were conducted in triplicate and results were expressed as cytotoxicity percentages $(\% \mathrm{C})$, calculated using the following equation:

$$
(\% \mathrm{C})=1-\frac{\left(\text { Do }_{570} \text { tumor cells }\right)}{\left(\text { Do }_{570} \text { control cells }\right)} \times 100
$$

Selectivity index: Selectivity index (SI) was expressed as the $\mathrm{IC}_{50}$ (control cells) / $\mathrm{IC}_{50}$ (tumor cell line) ratio. A selectivity index $>1$ indicates that cytotoxicity on tumor cell lines surpasses that on healthy non-tumor cells (Nugroho et al., 2013).

Statistical analysis: Mean inhibitory concentration $\left(\mathrm{IC}_{50}\right)$ was calculated with $95 \%$ confidence intervals by a linear regression equation and statistical analysis was performed using Prism 5.0 software (GraphPad, CA, USA). The global comparison was performed using two-way analysis of variance (ANOVA) followed by a Bonferroni's test for multiple comparisons. Significance levels of $\alpha=0.05$ and $\alpha=0.001$ were used.

\section{RESULTS}

Essential oils from fresh leaves of VM, VBJ and VBV identified by gas chromatography-mass spectrometry (GC-MS) showed 24, 10 and 16 components, respectively, 
TABLE 1

Chemical composition of the essential oils of Vismia macrophylla (VM) and $V$. baccifera (VBJ and VBV) collected in the Venezuelan Andes

TABLA 1

Composición química de los aceites esenciales de Vismia macrophylla (VM) y V. baccifera (VBJ y VBV) recolectadas en los Andes venezolanos

\begin{tabular}{|c|c|c|c|c|}
\hline Compounds* & IK & VM & VBJ & VBV \\
\hline$\alpha$-cubebene & 1347 & 0.4 & 0.8 & 1.8 \\
\hline$\alpha$-copaene & 1374 & 0.9 & 1.7 & 4.0 \\
\hline$\beta$-elemene & 1387 & 2.4 & 2.4 & 12.4 \\
\hline trans-caryophyllene & 1413 & 4.9 & - & 42.8 \\
\hline$\beta$-caryophyllene & 1415 & - & 73.4 & - \\
\hline$\beta$-copaene & 1420 & 0.4 & - & - \\
\hline trans- $\alpha$-bergamotene & 1434 & 3.9 & - & - \\
\hline$\alpha$-guaiene & 1438 & 0.3 & - & - \\
\hline$\beta$-farnesene & 1450 & 1.6 & - & - \\
\hline$\alpha$-humulene & 1451 & 0.9 & 12.6 & 7.4 \\
\hline$\gamma$-muurolene & 1474 & 0.6 & - & \\
\hline selina-4,11-diene & 1475 & - & & 1.4 \\
\hline$\gamma$-curcumene & 1480 & 1.1 & - & - \\
\hline trans-farnesene & 1481 & 2.2 & - & - \\
\hline germacrene-D & 1483 & 4.8 & 4.3 & 3.9 \\
\hline$\beta$-selinene & 1487 & 0.9 & - & 2.7 \\
\hline$\alpha$-selinene & 1494 & 1.8 & - & 4.2 \\
\hline$\alpha$-bulnesene & 1502 & 1.0 & - & \\
\hline eremophilane & 1503 & - & - & 9.6 \\
\hline$(\mathrm{E}, \mathrm{E})-\alpha$-farnesene & 1504 & 1.3 & - & - \\
\hline germacrene-A & 1506 & - & 1.7 & - \\
\hline$\gamma$-cadinene & 1510 & - & 1.1 & - \\
\hline$\delta$-cadinene & 1520 & 1.4 & 1.2 & 1.9 \\
\hline$\gamma$-bisabolene & 1529 & 44.4 & - & - \\
\hline trans-nerolidol & 1555 & 0.6 & - & - \\
\hline nerolidol & 1557 & - & 0.7 & 0.3 \\
\hline caryophyllene oxide & 1578 & - & - & 0.4 \\
\hline gossonorol & 1627 & 1.2 & - & - \\
\hline cubenol & 1642 & - & - & 0.3 \\
\hline$\alpha$-muurolol & 1644 & - & - & 0.4 \\
\hline epi- $\alpha$-muurolol & 1646 & 1.3 & - & - \\
\hline selin-11-en-4- $\alpha$-ol & 1650 & - & - & 1.7 \\
\hline$\beta$-bisabolol & 1665 & 14.9 & - & - \\
\hline$\alpha$-bisabolol & 1681 & 3.3 & - & - \\
\hline
\end{tabular}

* Chemical composition was determined by comparison of the MS of each component with Wiley GC/MS library data and its retention index (RI). representing $96.50 \%, 99.82 \%$ and 95.19 $\%$ of the total for each oil. These oils were characterized by a high percentage of mono, bi- and tricyclic sesquiterpenes 70-90 \%, with moderate to low presence of bicyclic oxygenated sesquiterpenes $4-18 \%$ and noncyclic oxygenated sesquiterpenes $4-10 \%$ of the total oil. The essential oil of VBJ was mainly composed of $\beta$-caryophyllene (73.4 \%), $\alpha$-humulene (12.6\%) and germacrene-D (4.3 $\%)$. VBV oil had trans-caryophyllene (42.8\%), $\beta$-elemene (12.4\%), $\alpha$-humulene (7.4\%) and eremophylene $(9.6 \%)$ as major components, while VM oil had $\gamma$-bisabolene (44.4\%) and $\beta$-bisabolol (14.9\%) in major proportions. The complete results of the three samples analyzed are detailed in Table 1.

In vitro cytotoxic activity was assessed in the three essential oil samples by using the MTT assay. VBJ inhibited the growth of PANC-1 $(12.26 \mu \mathrm{g} / \mathrm{ml}), \operatorname{SKBr} 3(4.99 \mu \mathrm{g} / \mathrm{ml})$ and MCF-7 $(20.49 \mu \mathrm{g} / \mathrm{ml})$; while the essential oil of VBV only showed activity against SKBr3 $(10.54 \mu \mathrm{g} / \mathrm{ml})$; and the VM essential oil did not present any activity against the tumor cells evaluated in this investigation (Table 2).

According to the statistical analysis, VBJ essential oil exhibited significant differences $(\mathrm{P}<0.001)$ for the tumor lines PANC-1 and MCF-7 with respect to the non-tumor cells, and significant differences $(\mathrm{P}<0.001)$ compared to the VBV and VM groups for each tumor line. Furthermore, VBV is statistically significant $(\mathrm{P}<0.001)$ for the tumor line SKBr3 with respect to the non-tumor cells, and also differs from the essential oil groups VBJ and VM in the SKBr3 tumor line (Table 2). On the other hand, VBV essential oil proved to be highly selective against $\mathrm{SKBr} 3$ cell line (9.5) and has no activity against non-tumor cells; showing a higher selectivity than Taxol ${ }^{\circledR}(0.74)$, here used as a reference drug. VBJ essential oil, despite presenting cytotoxic activity for all tumor lines, showed the same activity against non-tumor cells, which indicates its low selectivity. 
TABLE 2

$\mathrm{IC}_{50}$ values and selectivity index (SI) of essential oils obtained from Vismia baccifera and $V$. macrophylla on cell lines

TABLA 2

Índices de selectividad (IS) y valores de $\mathrm{IC}_{50}$ de los aceites esenciales obtenidos de Vismia baccifera y V. macrophylla sobre las líneas celulares

\begin{tabular}{lccccccc} 
& \multicolumn{3}{c}{$\mathrm{IC}_{50}(\mu \mathrm{g} / \mathrm{ml})$} & \multicolumn{3}{c}{ SI } \\
EOSamples & PANC-1 & $\mathrm{SKBr}$ & $\mathrm{MCF}-7$ & Hdf & PANC-1 & SKBr3 & MCF-7 \\
VBJ & $12.26 \pm 1.04^{\mathrm{ABa}}$ & $4.99 \pm 1.02^{\mathrm{BCa}}$ & $20.49 \pm 1.02^{\mathrm{ACa}}$ & $6.16 \pm 1.01^{\mathrm{Aa}}$ & 0.50 & 1.23 & 0.30 \\
VBV & $100 \pm 1.33^{\mathrm{B}}$ & $10.54 \pm 1.09^{\mathrm{ABCb}}$ & $100 \pm 1.92^{\mathrm{C}}$ & $100 \pm 1.83^{\mathrm{A}}$ & 1 & 9.49 & 1 \\
VM & $100 \pm 1.39$ & $100 \pm 1.28$ & $100 \pm 2.18$ & $100 \pm 3.30$ & 1 & 1 & 1 \\
Taxol $^{\circledR}$ & $0.048 \pm 1.13$ & $1.03 \pm 0.22$ & $0.14 \pm 0.03$ & $0.76 \pm 1.23$ & 15.83 & 0.74 & 5.43 \\
\hline
\end{tabular}

Values \pm standard deviation are shown $(\mathrm{N}=8)$. Shared capital letters $(\mathrm{A}, \mathrm{B}, \mathrm{C})$ along rows indicate significant differences $(\mathrm{P}<0.001)$ between control cells (Hdf) and different tumor cell lines detected in the $V$. baccifera Jaji (VBJ), V. baccifera El Valle (VBV) and $V$. macrophylla (VM) groups. Different lower case letters $(\mathrm{a}, \mathrm{b})$ in the same column indicate significant differences $(\mathrm{P}<0.001)$ between the essential oils of VBJ, VBV and VM by tumor cell lines. Two-way ANOVAs followed by Bonferroni corrections were carried out for multiple comparisons. Taxol ${ }^{\circledR}$ was used as reference drug. Values over 100 $\mu \mathrm{g} / \mathrm{ml}$ were considered as no active.

\section{DISCUSSION}

The chemical composition of VBJ, VBV and VM essential oils revealed that the VM sample exhibited a more complex mixture of components along with the presence of $\gamma$-bisabolene and $\beta$-bisabolol. However, it is important to point out that $\beta$-caryophyllene was only observed in VBJ sample at high concentration $(73.4 \%)$. Previous investigations conducted on same species collected from other locations at Mérida, Venezuela have revealed several differences in the composition of these oils. The essential oil obtained from barks of Vismia baccifera var. dealbata collected at Chiguará (1 250 m.a.s.l.) showed caryophyllene oxide (31.4\%), $\beta$-caryophyllene (26.4 $\%)$ and $\alpha$-zingibirene $(12.6 \%)$ as main components (Vizcaya et al., 2014), while leaves of same species were composed mainly by germacrene-D (15.8\%), $\alpha$-cadinol (14.5\%), epi- $\alpha$-cadinol (11.9\%), $\beta$-caryophyllene (10.1 $\%)$ and $\delta$-cadinene $(7.5 \%)$.

The oil obtained from the leaves of $V . b a c$ cifera collected at La Hechicera (1 800 m.a.s.l.) showed $\beta$-caryophyllene (45.7\%), valencene (12.3\%), $\beta$-elemene (10.7\%), $\alpha$-humulene $(8.9 \%)$ and germacrene-D $(6.3 \%)$ as major components (Buitrago et al., 2009) while fruits of the same species collected from the same location showed trans-cadin-1,4-diene (36.6\%), cis-cadin-1,4-diene (18.8\%) and $\beta$-caryophyllene (11.9\%) (Rojas et al., 2011). On the other hand, essential oil of leaves of $V$. macrophylla showed $\gamma$-bisabolene (44.4\%) and $\beta$-bisabolol (14.9\%), while the oil from the fruits was composed by germacrene-D (12.1 $\%), \delta$-cadinene $(10.7 \%)$ and $\gamma$-bisabolene $(22.3$ $\%)$ (Buitrago et al., 2015).

Despite the differences observed in the chemical composition of these oils, compounds like $\beta$-caryophyllene, germacrene $\mathrm{D}, \beta$-elemene and $\alpha$-humulene are present in all samples studied. Several investigations have explained that essential oil composition may vary considerably depending on the time of plant collection and are also influenced by environmental conditions at the harvesting date. In addition, the location where the plant is growing, either sun or shade, affects the composition and yield of the oil (Petinatti, Petinatti, Niehues, \& Peporine, 2012)

With respect to cytotoxic activity, VBJ essential oil proved to be active against the entirely cell lines assessed, with values between 
6.16 to $20.49 \mu \mathrm{g} / \mathrm{ml}$, being selective only to SKBr3 (SI 1.23), however, it showed activity against Hdf (Table 2). On the other hand, VBV showed a highly selective cytotoxic activity against SKBr3 cell line at $10.54 \mu \mathrm{g} / \mathrm{ml}$, SI 9.49, and had no activity against Hdf. It is important to highlight that according to the selectivity index (SI 0.74), Taxol $^{\circledR}$, used as reference drug, has no selectivity to this cell line. SKBr3 is considered a more aggressive and fast growing type of cancer than other carcinomas (Suárez et al., 2016). Thus, the results observed in the present investigation are considered a contribution to natural products research.

As far as we know, there are no published works regarding the cytotoxic activity of essential oils from any Vismia species, however, antiproliferative activity was evaluated on essential oils obtained from 15 plants collected in Colombia by MTT assay on MCF-7, HeLa and HepG-2. Four species out of the 15 showed activity against MCF-7 and HeLa cell lines $\left(\mathrm{IC}_{50} 50 \mu \mathrm{g} / \mathrm{ml}\right)$. GC-MS analysis revealed that $\beta$-caryophyllene was a major component in those essential oils (Velandia, Quintero, Stashenko, \& Ocazionez, 2018).

Ethical statement: authors declare that they all agree with this publication and made significant contributions; that there is no conflict of interest of any kind; and that we followed all pertinent ethical and legal procedures and requirements. All financial sources are fully and clearly stated in the acknowledgements section. A signed document has been filed in the journal archives.

\section{ACKNOWLEDGMENTS}

Co-authors Janne Rojas and Alexis Buitrago wish to acknowledge the CDCHTA for partial financial support (FA-599-17-08-A y FA-600-17-08-ED) for this investigation.

\section{RESUMEN}

Composición de aceites esenciales y actividad citotóxica en dos especies de plantas del género Vismia (Hypericaceae) de los Andes venezolanos. Introducción: El género Vismia pertenece a la familia Hypericaceae y comprende alrededor de 57 especies de las cuales 17 han sido ubicadas en Venezuela. Se han realizado investigaciones previas tanto en extractos como en compuestos puros aislados revelando actividad antimicrobiana, antioxidante y anti-VIH, entre otras actividades biológicas. Objetivo: El propósito de esta investigación es determinar la actividad citotóxica de los aceites esenciales de las hojas de Vismia baccifera Triana \& Planch (VBJ y VBV) y Vismia macrophylla Kunth (VM) recolectadas en tres localidades de la región andina venezolana. Métodos: Aceites esenciales obtenidos por hidrodestilación fueron analizados por cromatografía de gases-espectrometría de masas y su actividad citotóxica fue analizada siguiendo el método MTT (bromuro de 3-[4,5-dimetiltiazol-2-il]-2,5-difeniltetrazolio). Los aceites esenciales fueron ensayados frente a células tumorales humanas SKBr3, MCF-7 y PANC-1, dos carcinomas de mama y un adenocarcinoma pancreático del tipo ductal, usando cultivos primarios de fibroblastos de dermis humana como células no tumorales. Resultados: $\beta$-cariofileno y trans-cariofileno estuvieron presentes como compuestos mayoritarios en VBJ y VBV, respectivamente, mientras que $\gamma$-bisaboleno fue el componente principal en la muestra VM. El aceite esencial de $V$. baccifera mostró actividad anticancerígena frente a SKBr3, MCF-7 y PANC1. El índice de selectividad reveló que VBV es altamente selectivo frente a la línea celular SKBr3 y no presenta actividad contra las células no tumorales. Conclusiones: Estos resultados se consideran una contribución a la investigación de los productos naturales y los datos pueden ser de utilidad en futuras investigaciones sobre el cáncer.

Palabras clave: fibroblastos; $\beta$-cariofileno; $\gamma$-bisaboleno; MTT; MCF-7; PANC-1; SKBr3.

\section{REFERENCES}

Adams, R. (2007). Identification of essential oil components by gas chromatography/ mass spectrometry. Illinois, United States: Allured Publishing Corporation, Carol Stream.

Angiosperm Phylogeny Group. (2009). An update of the Angiosperm Phylogeny Group classification for the orders and families of flowering plants: APG III. Botanical Journal of the Linnean Society, 161(2), 105-121. 
Aristiguieta, L. (1973). Familias y géneros de los árboles de Venezuela. Caracas, Venezuela: Universidad Central de Venezuela, Edición Especial del Instituto Botánico.

Buitrago, A., Rojas, J., Rojas, L., \& Peñaloza, Y. (2016). In Vitro antioxidant activity and qualitative phytochemical analysis of two Vismia (Hypericaceae) species collected in Los Andes, Venezuela. Revista de Biología Tropical, 6(4), 1431-1439.

Buitrago, A., Rojas, J., Rojas, L., Velasco, J., Morales, A., Peñaloza, Y., \& Díaz, C. (2015). Essential oil composition and antimicrobial activity of Vismia macrophylla leaves and fruits collected in Táchira-Venezuela. Natural Product Communications, 10(2), 375-377.

Buitrago, A., Rojas, L., Rojas, J., Buitrago, D., Usubillaga, A., \& Morales, A. (2009). Comparative study of the chemical composition of the essential oil from fresh leaves of Vismia baccifera var. dealbata (Guttiferae) collected in two different locations in MéridaVenezuela. Journal of Essential Oil Bearing Plants, 12, 651-655.

Crocketta, S.L., \& Robson, N.K. (2011). Taxonomy and chemotaxonomy of the genus Hypericum. Medicinal and Aromatic Plant Science and Biotechnology, 5(1), 1-13.

Davies, N. (1990). Gas chromatographic retention indices of monoterpenes and sesquiterpenes on methyl silicone and carbowax 20 M. phases. Journal of Chromatography A, 503, 1-24.

Ferreira N., Marchesine A., Lucchese, A., Lopes R., Santos O., \& Maia, B. (2015). Antinociceptive and antiinflammatory activity of hexanic extract leaves of Vismia guianensis Aubl. in mice. Revista de Ciências Médicas e Biológicas, 14(1), 69-73.

Gomes, M.J.N., Silva, S.N., Ribeiro, R.M., Abreu, I.C., Borges, R.M.O., \& Borges, R.A.C. (2009). Screening farmacológico das folhas de Vismia reichardtiana (O. Ktze) Ewan-Guttiferae. Revista Cadernos de Pesquisa, 16(1), 5-10.

Gómez-Cansino, R., Espitia-Pinzón, C.I., Campos-Lara, M.G., Guzmán-Gutiérrez, S.L., Segura-Salinas, E., Echeverría-Valencia, G., ... Reyes-Chilpa, R. (2015). Antimycobacterial and HIV-1 Reverse transcriptase activity of Julianaceae and Clusiaceae plant species from Mexico. Evidence-Based Complementary and Alternative Medicine, 2015(1), 1-8. DOI: doi. org/10.1155/2015/183036

Hussain, H., Hussain, J., Al-Harrasi, A., Saleem, M., Green, I.R., van Ree, T., \& Ghulam, A. (2012). Chemistry and biology of genus Vismia. Pharmaceutical Biology, 50(11), 1448-1462.

Mosmann, T. (1983). Rapid colorimetric assay for cellular growth and survival: application to proliferation and cytotoxicity assay. Journal of Immunological Methods, 65, 55-63.

Nugroho, A.E., Hermawan, A., Putri, D.D., Novika, A., Meiyanto, E., \& Kawaichi, M. (2013). Combinational effects of hexane insoluble fraction of Ficus septica Burm. F. and doxorubicin chemotherapy on T47D breast cancer cells. Asian Pacific Journal of Tropical Biomedicine, 3(4), 297-302.

Petinatti, P., Petinatti, P., Niehues, M., \& Peporine L. (2012). Exogenous influences on plant secondary metabolite levels. Animal Feed Science and Technology, 176(1-4), 5-16.

Raybaudi-Massilia, R., Suárez, A.I., Arvelo, F., Sojo, F., Mosqueda-Melgar, J., Zambrano, A., \& CalderónGabaldón, M.I. (2015). An analysis In-vitro of the cytotoxic, antioxidant and antimicrobial activity of aqueous and alcoholic extracts of Annona muricata L. seed and pulp. British Journal of Applied Science \& Technology, 5(4), 333-341.

Rojas, J., Buitrago, A., Rojas, L., Morales, A., Lucena, M., \& Baldovino, S. (2011). Essential oil composition and antibacterial activity of Vismia baccifera fruits collected from Mérida, Venezuela. Natural Product Communications, 6, 699-700.

Rojas, J., Buitrago, A.A., Arvelo, F.A., Sojo, F.J., \& Suarez, A.I. (2017). Cytotoxic activity of different polar extracts from Vismia baccifera and Vismia macrophylla (Hypericaceae) collected in Venezuela. Journal of Pharmacy \& Pharmacognosy Research, 5(5), 320-326.

Ruhfel, B., Bittrich, V., Bove, C., Gustafsson, M., Philbrick, C., Rutishauser, R., ... Davis, C. (2011). Phylogeny of the clusioid clade (Malpighiales): evidence from the plastid and mitochondrial genomes. American Journal of Botany, 98, 306-325.

Salas, F., Rojas, J., Morales, A., Ramos-Nino, M.E., \& Colmenares, N.G. (2008). In vitro cytotoxic activity of sesamin isolated from Vismia baccifera var. dealbata Triana \& Planch (Guttiferae) collected from Venezuela. Natural Product Communications, 3(10), 1705-1708.

Silvestre, R.G., de Moraes, M.M., Lins, A.C.S., Ralph, M.T., Lima-Filho, J.V., Camara, C.A., \& Silva, T.M.S. (2012). Chemical composition, antibacterial and antioxidant activities of the essential oil from Vismia guianensis fruits. African Journal of Biotechnology, 11(41), 9888-9893.

Stevens, P.F. (2007). Hypericaceae. In K. Kubitzki (Ed.), The families and genera of vascular plants (pp. 194201). Berlin, Germany: Springer Verlag.

Suárez, A.I., Mancebo, M., Delle-Monache, F., Tirric, M.M., Sojo, F., Arvelo, F., \& Tillett, S. (2016). A new indole-alkaloid and a new phenolic-glycoside with 
cytotoxic activity from Strychnos fendleri. Natural Product Research, 30(4), 399-405.

Tala, M.F., Tamokou, J.D., Tchakam, P.D., Tane, P., Kuiate, J.R., \& Wabo, H.K. (2011). Antioxidant xanthones, anthraquinoes and semi-synthetic derivatives from Vismia rubescens and Vismia laurentii. Pharmacologyonline, 3, 1410-1418.

van Meerloo, J., Kaspers, G.J, \& Cloos, J. (2011). Cell sensitivity assays: The MTT assay. Methods in Molecular Biology, 731, 237-245.

Velandia, S.A., Quintero, E., Stashenko, E.E., \& Ocazionez, R.E. (2018). Actividad antiproliferativa de aceites esenciales de plantas cultivadas en Colombia. Acta Biológica Colombiana, 3(2), 189-198.

Vizcaya, M., Morales, A., Rojas, J., \& Nuñez, R. (2012). Revisión bibliográfica sobre la composición química y actividades farmacológicas del género Vismia (Guttiferae). Boletín Latinoamericano y del Caribe de Plantas Medicinales y Aromaticas, 11(1), 12-34.

Vizcaya, M., Pérez, C., Rojas, J., Rojas-Fermín, L., Plaza, C., Morales, A., \& Pérez, P. (2014). Composición química y evaluación de la actividad antifúngica del aceite esencial de corteza de Vismia baccifera var. Dealbata. Revista de la Sociedad Venezolana de Microbiología, 34, 86-90. 